Article

\title{
Production and Surfactant Properties of Tert-Butyl $\alpha$-D-Glucopyranosides Catalyzed by Cyclodextrin Glucanotransferase
}

\author{
Humberto Garcia-Arellano ${ }^{1,2}{ }^{(D}$, Jose L. Gonzalez-Alfonso ${ }^{1} \mathbb{D}$, Claudia Ubilla ${ }^{1,3}$, \\ Francesc Comelles ${ }^{4}$, Miguel Alcalde ${ }^{1}$ (D), Manuel Bernabé ${ }^{5,+}$, José-Luis Parra ${ }^{4}$, \\ Antonio O. Ballesteros ${ }^{1}$ and Francisco J. Plou ${ }^{1, *(D)}$ \\ 1 Instituto de Catálisis y Petroleoquímica, CSIC, 28049 Madrid, Spain \\ 2 Departamento de Ciencias Ambientales, División de Ciencias Biológicas y de la Salud, Universidad \\ Autónoma Metropolitana, Unidad Lerma, Av. de las Garzas 10, Lerma de Villada, \\ Estado de México 52006, Mexico \\ 3 Escuela de Ingeniería Bioquímica, Pontificia Universidad Católica de Valparaíso, Valparaíso 2147, Chile \\ 4 Instituto de Investigaciones Químicas y Ambientales, CSIC, 08034 Barcelona, Spain \\ 5 Instituto de Química Orgánica, CSIC, 28006 Madrid, Spain \\ * Correspondence: fplou@icp.csic.es; Tel.: +34-915854869 \\ † Dedicated to the memory of Prof. Manuel Bernabé, deceased on April 2018.
}

Received: 28 May 2019; Accepted: 26 June 2019; Published: 29 June 2019

\begin{abstract}
While testing the ability of cyclodextrin glucanotransferases (CGTases) to glucosylate a series of flavonoids in the presence of organic cosolvents, we found out that this enzyme was able to glycosylate a tertiary alcohol (tert-butyl alcohol). In particular, CGTases from Thermoanaerobacter sp. and Thermoanaerobacterium thermosulfurigenes EM1 gave rise to the appearance of at least two glycosylation products, which were characterized by mass spectrometry (MS) and nuclear magnetic resonance (NMR) as tert-butyl- $\alpha$-D-glucoside (major product) and tert-butyl- $\alpha$-D-maltoside (minor product). Using partially hydrolyzed starch as glucose donor, the yield of transglucosylation was approximately $44 \%$ (13 g/L of tert-butyl- $\alpha$-D-glucoside and $4 \mathrm{~g} / \mathrm{L}$ of tert-butyl- $\alpha$-D-maltoside). The synthesized tert-butyl- $\alpha$-D-glucoside exhibited the typical surfactant behavior (critical micellar concentration, 4.0-4.5 $\mathrm{mM}$ ) and its properties compared well with those of the related octyl- $\alpha$-D-glucoside. To the best of our knowledge, this is the first description of an enzymatic $\alpha$-glucosylation of a tertiary alcohol.
\end{abstract}

Keywords: biocatalysis; glycosidases; transglycosylation; cyclodextrin glycosyltransferases; alkyl glucosides; biosurfactants

\section{Introduction}

Cyclodextrin glucanotransferases-also known as cyclodextrin glycosyltransferases (CGTases, EC 2.4.1.19) — are extracellular enzymes included in the so-called $\alpha$-amylase family GH13 [1] and are able to convert starch and related maltodextrin substrates into nonreducing, cyclic glucooligosaccharides termed cyclodextrins (CDs) [2]. CDs are formed by an intramolecular transglycosylation reaction in which 6,7 , or 8 glucosyl residues are linked by $\alpha(1 \rightarrow 4)$ glycosidic bonds, giving rise to the formation of $\alpha, \beta$, or $\gamma$-CDs, respectively [3]. Besides cyclization, CGTases also catalyze three additional reactions: Coupling, i.e., the aperture of the $\mathrm{CD}$ ring and subsequent transfer of glucose residues to acceptors; disproportionation, i.e., the transfer reaction between two linear dextrins to form maltooligosaccharides of different sizes; and hydrolysis, in which the acceptor is a $\mathrm{H}_{2} \mathrm{O}$ molecule [4]. It is worth noting that CGTases display a weak hydrolyzing activity (1.5-3.0 U/mg protein) [5]. The main reaction catalyzed 
by these enzymes (in terms of specific activity) is the intermolecular transglycosylation (coupling and disproportionation, employing CDs or maltodextrins as glucosyl donors, respectively) $[6,7]$. In the presence of certain carbohydrates such as sucrose, CGTase also transfers glucosyl moieties yielding the so-called acceptor products [8].

The enzyme CGTase has proved an exceptional capability to glucosylate compounds of different nature employing starch, maltodextrins, or cyclodextrins as glucosyl donors [9,10]. Apart from monosaccharides and disaccharides [11,12], other compounds such as flavonoids [13,14], vitamins [15], sugar alcohols [16], sweet glycosides [17], and polyols [18] have been successfully used as acceptor molecules for the intermolecular transglycosylation. Unfortunately, one of the main drawbacks of CGTases is that their product selectivity is not very high, because the enzyme displays its four activities simultaneously [19]. Furthermore, the formation of a homologous series of polyglucosylated products is normally described with this enzyme [20-22]. As a result, a low yield of the desired glycosylated product is typically obtained [23]. Several strategies have been assessed to improve the transglycosylation activity of CGTases, including protein engineering [24-26], chemical modification [7], immobilization [27,28], and the addition of cosolvents and additives [29-31]. Bacterial CGTases are produced mainly by the genus Bacillus [32], although Micrococcus and Klebsiella species had also been reported as producers.

For many of these acceptor reactions catalyzed by CGTases and other glycosidic enzymes, a cosolvent is needed to increase the solubility of the acceptor in the reaction medium. A requirement of the solvent is that it cannot act as acceptor itself, because this could cause a reduction of the yield of the transglycosylation and lead to the appearance of undesired side products. For this reason, primary and secondary alcohols are barely used in these transglycosylations. In fact, the synthesis of alkyl glycosides has been widely reported using the reverse hydrolysis reaction catalyzed by glycosidases employing mainly primary and secondary alcohols as acceptors [33-35]. Typical cosolvents for transglycosylation reactions include acetonitrile, DMSO, ethers, tertiary alcohols, etc. [22,23,36], and more recently, biomass-derived solvents and ionic liquids [37,38].

In this work, while testing the ability of CGTases to glucosylate a series of flavonoids in presence of organic cosolvents, we found out that this enzyme was able to glycosylate a tertiary alcohol (tert-butyl alcohol). We report herein the enzymatic synthesis of two novel alkyl glycoside derivatives, namely tert-butyl- $\alpha$-D-glucoside and tert-butyl $\alpha$-D-maltoside. Alkyl glucosides (AGs) are non-ionic surface-active agents with extensive applications in food, cosmetic, and detergent industries $[39,40]$, in part due to their antimicrobial activity, biodegradability, and low toxicity. The surfactant properties of the major synthesized product were compared with those of related alkyl glycosides.

\section{Results and Discussion}

\subsection{Glucosylation of Tert-Butyl Alcohol by CGTases and Characterization of Products}

In our laboratory we are studying the application of different CGTases to synthesize glucosylated derivatives of polyphenols with bioactive properties [41]. Many of these flavonoids are scarcely soluble in water, which implies the need of using a miscible cosolvent to increase the solubility of the acceptor. While screening a series of cosolvents $($ at $30 \% \mathrm{v} / \mathrm{v})$ for the glycosylation of polyphenols, we observed in the HPLC chromatogram, when using tert-butyl alcohol, the appearance of several peaks with retention times lower than the corresponding to glucose (Figure 1). Such peaks were also present in the control reaction in absence of the acceptor, but not in the control experiments lacking enzyme, sugar donor, or tert-butyl alcohol. Thus, it seemed that CGTase was able to glycosylate the tertiary alcohol tert-butyl alcohol.

We screened four CGTases from different bacterial species (Table 1) for their transglycosylation efficiency towards tert-butyl alcohol at $60^{\circ} \mathrm{C}$. First, the transglycosylation activity of these enzymes was determined with a test based on the use of p-nitrophenyl- $\alpha$-D-maltoheptaoside-4,6-O-ethylidene (EPS) as glucosyl donor and maltose as acceptor [12]. For commercial CGTases, the preparations 
were partially purified by a PD-10 desalting column (GE Healthcare, Chicago, IL, USA) to eliminate low-molecular-weight contaminants that could interfere with our reaction. The transglycosylation experiments towards tert-butyl alcohol were carried out employing the same amount of EPS enzyme units.

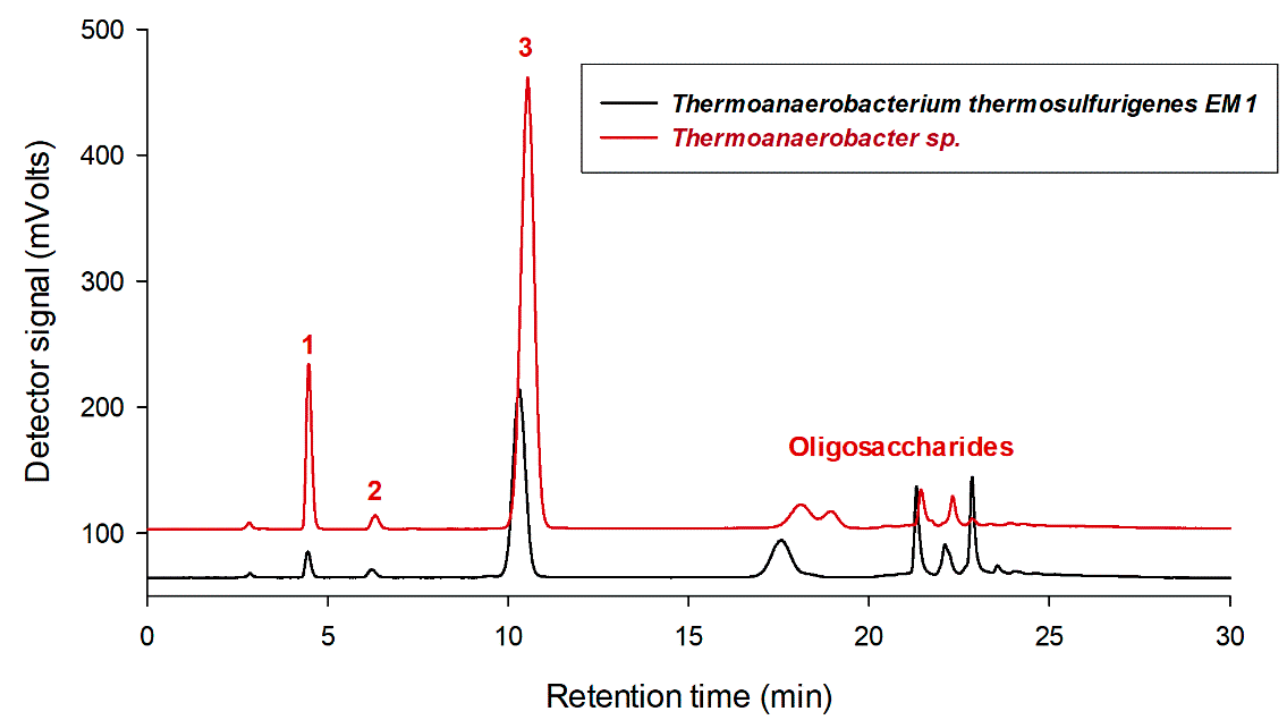

Figure 1. HPLC chromatogram of the reaction mix after $24 \mathrm{~h}$ displaying the acceptor products of tert-butyl alcohol synthesized with CGTases from Thermoanaerobacter $\mathrm{sp}$. and Thermoanaerobacterium thermosulfurigenes EM1. Reaction conditions: Soluble starch $(30 \mathrm{~g} / \mathrm{L}), 30 \%$ tert-butyl alcohol, $10 \mathrm{mM}$ sodium citrate buffer ( $\mathrm{pH} 5.5)$, CGTase $\left(0.4 \mathrm{U} / \mathrm{mL}\right.$, EPS method), and $60{ }^{\circ} \mathrm{C}$. (1) Main glucosylation product; (2) minor glucosylation product; and (3) glucose.

Table 1. Cyclodextrin glucanotransferases (CGTases) screened for the glucosylation of tert-butyl alcohol.

\begin{tabular}{|c|c|c|}
\hline Source & Protein $(\mathrm{mg} / \mathrm{mL})$ & $\begin{array}{l}\text { Transglycosylation Activity } \\
\qquad(\mathrm{U} / \mathrm{mL})^{\mathrm{a}}\end{array}$ \\
\hline Thermoanaerobacter sp. & 2.88 & 37.1 \\
\hline $\begin{array}{l}\text { Thermoanaerobacterium } \\
\text { thermosulfurigenes EM1 }\end{array}$ & 0.77 & 43.1 \\
\hline Geobacillus sp. & 2.63 & 66.4 \\
\hline Bacillus circulans 251 & 2.79 & 152.7 \\
\hline
\end{tabular}

${ }^{a}$ Measured by the EPS method.

The TLC screening showed that the only enzymes that led to a noticeable production of glucosylated products, under the tested conditions, were the CGTases from Thermoanaerobacter sp. (Toruzyme 3.0L) and Thermoanaerobacterium thermosulfurigenes EM1. No appreciable formation of the new acceptor derivatives was observed with the rest of the CGTases. Moreover, in the case of Bacillus circulans and Geobacillus sp. CGTases, tert-butyl alcohol seemed to produce an inhibitory effect on enzyme activity. Figure 1 shows the HPLC chromatograms obtained with the CGTases from T. thermosulfurigenes EM1 and Thermoanaerobacter sp. after $24 \mathrm{~h}$ of reaction.

Several carbohydrates (maltose, $\alpha$-cyclodextrin, $\beta$-cyclodextrin, and partially hydrolyzed starch) were compared as sugar donors in the transglycosylation reaction towards tert-butyl alcohol with Thermoanaerobacter sp. CGTase. All the substrates tested yielded the expected transglycosylation products. However, partially hydrolyzed starch was selected as the best glucosyl donor for further experiments due to its availability and lower cost.

With the aim to clearly identify the nature of the new synthesized products, the two main peaks in the chromatograms of Figure 1 were isolated by semipreparative HPLC. Both products were purified at a high degree ( $>98 \%$ ). The major product $(\mathbf{1})$ was a white solid whereas the minor derivative 
(2) showed an oily appearance. The molecular weight was established by MS-QTOF using ionization by electrospray (see Supplementary Materials, Figures S1 and S2). For compound 1, the main peak in the MS spectrum (positive mode) was at $m / z 259.11$ that corresponded to the $\mathrm{M}+[\mathrm{Na}]^{+}$ion of the tert-butyl glucoside. For compound 2, the major signal of the MS spectrum in positive mode was at $\mathrm{m} / \mathrm{z} 421.17$ that fits with the $\mathrm{M}+[\mathrm{Na}]^{+}$ion of the tert-butyl maltoside. The identity of the products was clearly established by ${ }^{13} \mathrm{C}$ and ${ }^{1} \mathrm{H}$ NMR analysis. NMR data confirmed the $\alpha$-configuration of the glucosyl moieties. The structure of the synthesized compounds is represented in Figure 2. The major compound was tert-butyl-O- $\alpha$-D-glucopyranoside and the minor product the corresponding $\alpha$-D-maltoside. A particular feature of CGTase is the formation of several polyglucosylated products (the so-called homologous series) with different acceptors [8,42].

tert-butyl-O- $\alpha$-D-glucopyranoside. 1H-NMR $(\delta): 5.07$ (d, $\left.1 \mathrm{H}, \mathrm{H}-1, J_{1,2}=3.9 \mathrm{~Hz}\right)$; 3.78-3.66 (m, 3H, $\mathrm{H}-5+\mathrm{H}-6 \mathrm{a}+\mathrm{H}-6 \mathrm{~b}) ; 3.61$ (t, 1H, H-3, J2,3 = 9.4, $\left.J_{3,4}=9.2 \mathrm{~Hz}\right) ; 3.31$ (dd, 1H, H-2); 3.28 (t, 1H, H-4, $J_{4,5}=9.3 \mathrm{~Hz}$ ); 1.30 (s, 9H, t-butyl). 13C-NMR (8): 94.6 (C-1); 75.2 (C-3); 73.5 (C-5); 73.1 (C-2); 72.0 (C-4); 62.7 (C-6); 28.9 (tert-butyl).

tert-butyl-O- $\alpha$-D-maltoside. 1H-NMR ( $\delta$ ): $5.13\left(\mathrm{~d}, 1 \mathrm{H}, \mathrm{H}-1^{\prime}, J_{1^{\prime}, 2^{\prime}}=3.9 \mathrm{~Hz}\right) ; 5.06(\mathrm{~d}, 1 \mathrm{H}, \mathrm{H}-1$, $\left.J_{1,2}=3.8 \mathrm{~Hz}\right) ; 3.89-3.64\left(\mathrm{~m}, 6 \mathrm{H}, \mathrm{H}-5+\mathrm{H}-6 \mathrm{a}+\mathrm{H}-6 \mathrm{~b}+\mathrm{H}-5^{\prime}+\mathrm{H}-6^{\prime} \mathrm{a}+\mathrm{H}^{\prime}-6 \mathrm{~b}\right) ; 3.82\left(\mathrm{dd}, 1 \mathrm{H}, \mathrm{H}-3, J_{2,3}=9.6\right.$, $\left.J_{3,4}=9.0 \mathrm{~Hz}\right) ; 3.62\left(\mathrm{t}, 1 \mathrm{H}, \mathrm{H}-3^{\prime}, J_{2^{\prime}, 3^{\prime}}=9.9, J_{3^{\prime}, 4^{\prime}}=9.0 \mathrm{~Hz}\right) ; 3.50\left(\mathrm{t}, 1 \mathrm{H}, \mathrm{H}-4, J_{4,5}=9.8 \mathrm{~Hz}\right) ; 3.43(\mathrm{dd}, 1 \mathrm{H}$, H-2'): 3.37 (dd, $1 \mathrm{H}, \mathrm{H}-2) ; 3.26\left(\mathrm{t}, 1 \mathrm{H}, \mathrm{H}-4^{\prime}, J_{4^{\prime}, 5^{\prime}}=9.3 \mathrm{~Hz}\right) ; 1.27$ (s, 9H, t-butyl). 13C-NMR (8): 102.9 (C-1'); 94.5 (C-1); 81.9 (C-4); $75.1+75.0\left(\mathrm{C}-3^{\prime}+\mathrm{C}^{\prime} 5^{\prime}\right) ; 74.7$ (C-2'); 74.3 (C-3); 73.1 (C-2); 71.8 (C-5); 71.5 (C-4'); 62.8 (C-6); 62.1 (C-6'); 28.9 (tert-butyl).
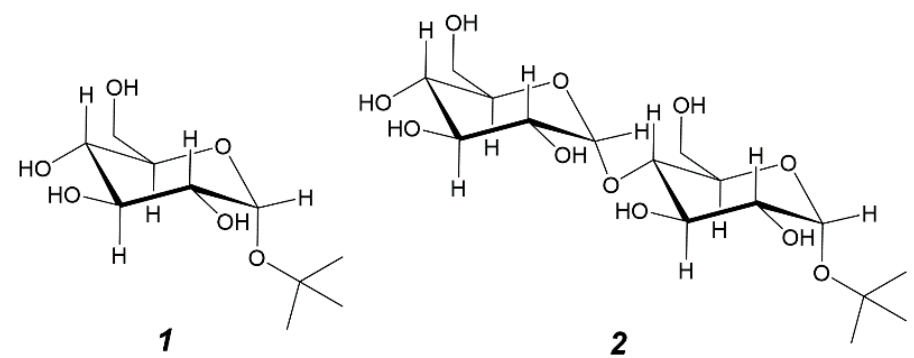

Figure 2. Chemical structure of the synthesized glycosides: (1) tert-butyl-O- $\alpha$-D-glucopyranoside and (2) tert-butyl-O- $\alpha$-D-maltoside.

It is remarkable that CGTases can use a sterically hindered alcohol as acceptor. Alcohols have been frequently used as additives in the reaction media to improve or direct the synthesis of specific cyclodextrins by CGTases. However, to the extent of our knowledge, no other reports describe the synthesis of alkyl glucosides catalyzed by CGTases. Svensson et al. synthesized dodecyl- $\beta$-maltooctaoside with CGTase from $B$. macerans by an indirect method based on the lengthening of dodecyl- $\beta$-maltoside using $\alpha$-cyclodextrin as glucosyl donor [43]. In this context, CGTases are able to transglycosylate polyhydroxylated compounds such as trimethylolpropane or glycerol [44].

The synthesis of alkyl glycosides has been manly achieved using the reverse hydrolysis reaction catalyzed by glycosidases $[45,46]$. Glycosidases show remarkable chemoselectivity for primary and secondary alcohols as well as phenols, but tertiary alcohols are not easily recognized as substrates. For the glycosylation of phenols, CGTase is one of the best options because its hydrolytic activity is very low. Since phenol is a good leaving group, glycosidases typically fast hydrolyze the synthesized phenyl glycosides, thus lowering the yield.

In general, secondary alcohols are glycosylated more slowly than primary ones by a factor of 3-5 [33]. Tertiary alcohols were considered unreactive in such enzymatic reactions until 1996, when Fischer et al. demonstrated that a tertiary alcohol (2-methyl-2-butanol) could act as nucleophile in a reaction catalyzed by the $\beta$-glucosidase from Pyrococcus furiosus, using cellobiose as glucosyl donor [47]. Later, Svasti et al. described the synthesis of tertiary $\beta$-glucosides catalyzed by a $\beta$-glucosidase from 
cassava [34]. However, this enzyme requiered activated $p$-nitrophenyl ( $\mathrm{pNP}$ ) glycosides as sugar donors and was not efficient with mono- and disaccharides. In addition, the synthesized $\beta$-glucoside was fast hydrolyzed as a consequence of the hydrolytic activity of the enzyme. Jiang et al. were able to synthesize tert-butyl $\beta$-D-xyloside and xylobioside with xylan as sugar donor, in the presence of $20 \%$ tert-butyl alcohol, employing a xylanase from Thermotoga maritima [48]. Kongsaree et al. reported in 2010 that linamarase (a cyanogenic $\beta$-glucosidase) also catalyzed transglucosylation reactions with tertiary alcohols as acceptors and pNP-glycosides as donors [49].

Regarding the formation of alkyl glycosides of tertiary alcohols with $\alpha$-configuration, Simerska et al. were the first in reporting the enzymatic $\alpha$-glycosylation of two sterically hindered alcohols, namely tert-butyl and tert-amyl alcohol; the enzyme was a $\alpha$-galactosidase from Talaromyces flavus, with pNP $\alpha$-galactoside as donor, yielding the corresponding $\alpha$-D-galactopyranosides [50]. To our knowledge, our work is the first report of an enzymatic $\alpha$-glucosylation of a tertiary alcohol. The chemical synthesis of tert-butyl $\alpha$-glucosides is quite complex and usually gives rise to a mixture of anomers [51].

\subsection{Progress of Tert-Butyl Alcohol Glucosylation by Thermoanaerobacter sp. CGTase}

In order to dismiss that none of the contaminant enzymes in the Toruzyme preparation was responsible of tert-butyl alcohol glycosylation, the CGTase from Thermoanaerobacter sp. was purified to homogeneity by sequential chromatography steps on DEAE-Sepharose and $\alpha$-cyclodextrin-activated Superose. We observed that the introduction of an ion-exchange chromatography step before the commonly used affinity step rendered a pure enzyme as confirmed by SDS-PAGE (Figure 3).

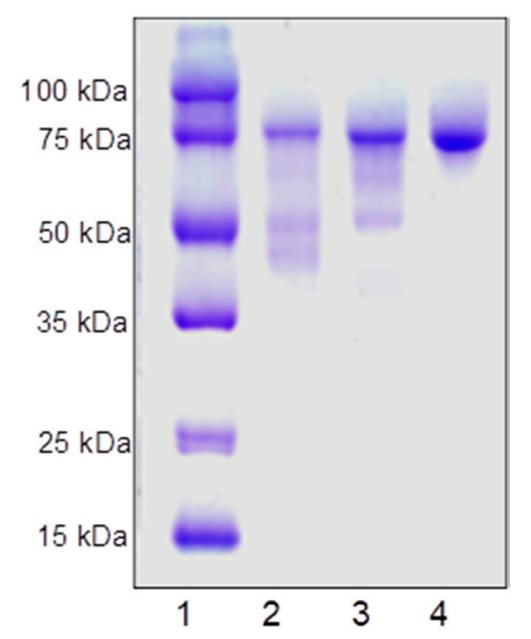

Figure 3. Purification of CGTase from Thermoanaerobacter sp. Lane 1, molecular mass markers; lane 2, crude extract; lane 3, DEAE chromatography step; and lane 4, affinity chromatography step.

We evaluated the production of tert-butyl-glucosides with the purified enzyme in a batch reactor employing 30\% tert-butyl alcohol. Although Thermoanaerobacter sp. CGTase has an optimal temperature around $90{ }^{\circ} \mathrm{C}$ [52], the reaction was carried out at $60^{\circ} \mathrm{C}$ to avoid starch browning and evaporation over time. Figure 4 depicts the progress of the reaction. Approximately $13 \mathrm{~g} / \mathrm{L}$ of tert-butyl glucoside were produced after $200 \mathrm{~h}$ of reaction. In the case of the maltoside derivative, a plateau after $60 \mathrm{~h}$ was reached yielding only $4 \mathrm{~g} / \mathrm{L}$. Considering that the initial concentration of soluble starch was $30 \mathrm{~g} / \mathrm{L}$, and that the sugar donor is the limiting reagent in the reaction, the yield of the tert-butyl glycosides was approximately $44 \%$. 


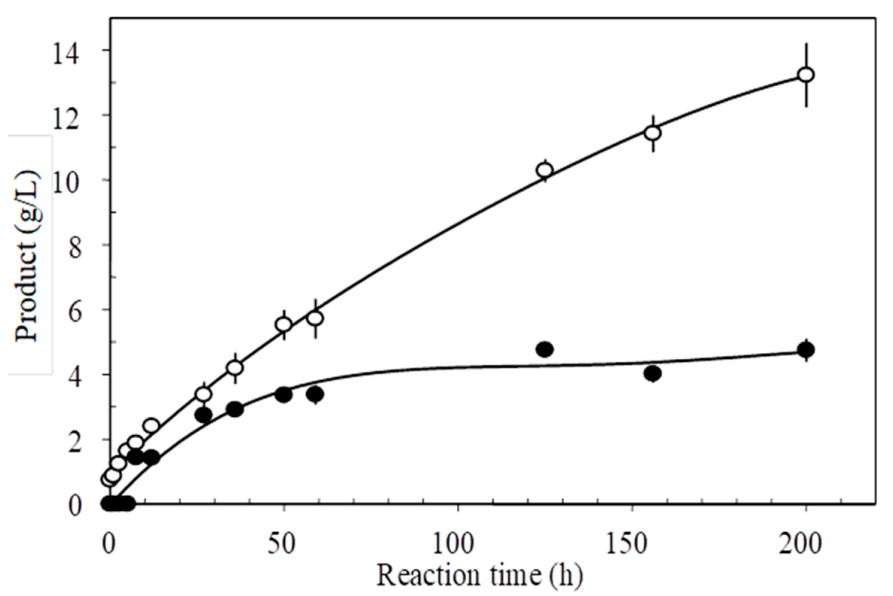

Figure 4. Progress of tert-butyl alcohol glucosylation by CGTase from Thermoanaerobacter sp. Open circles, $\alpha$-glucoside derivative; filled circles, $\alpha$-maltoside derivative. Reaction conditions: Soluble starch (30 g/L), 30\% tert-butyl alcohol, $10 \mathrm{mM}$ citrate buffer ( $\mathrm{pH} 5.5), 0.4 \mathrm{U} / \mathrm{mL}$ CGTase (transglycosylation activity, EPS method), and $60{ }^{\circ} \mathrm{C}$.

\subsection{Surfactant Properties of Tert-Butyl Glucoside}

Anomerically pure alkyl glucosides (AGs) are very useful in pharmaceutical and biomedical applications [53] due to their compatibility with biological systems that arise from the presence of the sugar head groups attached to the molecule. AGs do not denature enzymes and proteins, and in consequence are commonly used in protein extraction from cellular membranes [54]. AGs, unlike other sugar-based surfactants, are quite stable under alkaline conditions. In previous work, while studying several resveratrol glucosides, we demonstrated that the $\alpha$-configuration gave rise to a superior surfactant performance when compared with $\beta$-configuration [9].

The surfactant properties of the monoglucosylated derivative were measured and compared with the reference compound octyl- $\alpha$-D-glucoside (Figure 5). Our results suggest a similar surfactant behavior for both compounds. The synthesized tert-butyl glucoside behaves as a typical surfactant, defined by a linear descent of the surface tension vs. the logarithmic concentration of the surfactant, reaching a well-defined critical micellar concentration (CMC). CMC values of the tert-butyl and octyl $\alpha$-derivatives were closely similar. It is worth noting that the relatively small tert-butyl group seems to be equivalent to the bulky octyl group for micelle formation.

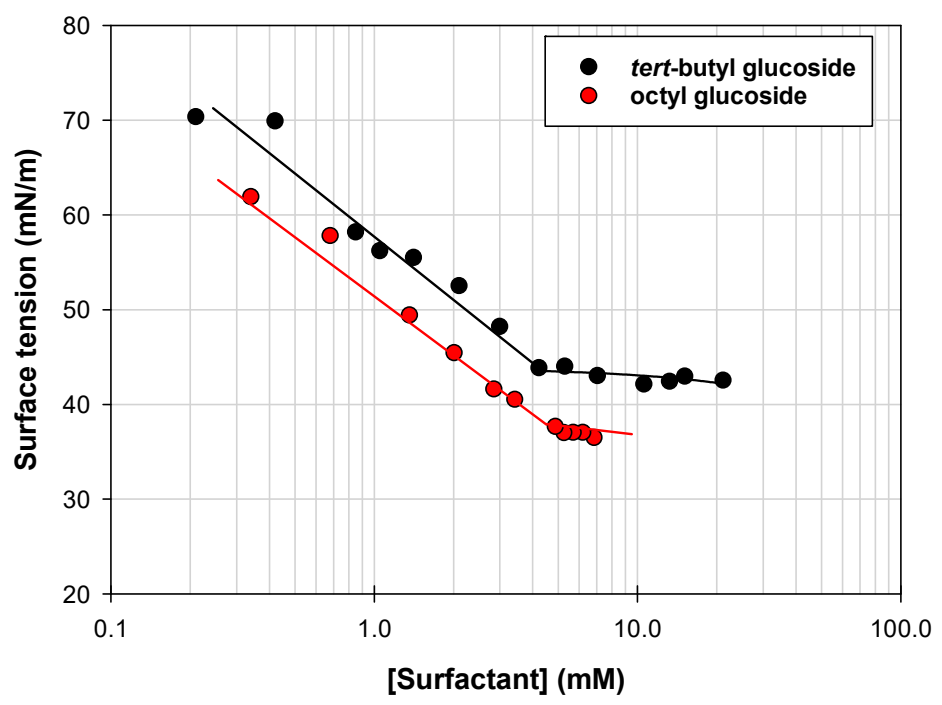

Figure 5. Variation of surface tension vs. concentration for tert-butyl and octyl glucosides. 
The main surfactant parameters of both compounds are summarized in Table 2. The surface tension at CMC is slightly higher for the tert-butyl glucoside with respect to the octyl derivative. As expected, the average area occupied per each molecule of adsorbed surfactant at the saturated water-air interface $(A)$ was higher for the tert-butyl glucoside compared with the octyl glucoside. The parameter $p \mathrm{C} 20$, which is directly related to the efficiency of a surfactant, was only $10 \%$ higher for octyl- $\alpha$-glucoside compared with the tert-butyl derivative.

Table 2. Surfactant properties of tert-butyl-O- $\alpha$-D-glucoside and octyl-O- $\alpha$-D-glucoside.

\begin{tabular}{ccc}
\hline Property & Tert-butyl- $\alpha$-glucoside & Octyl- $\alpha$-glucoside \\
\hline CMC $(\mathbf{m M})$ & $4.0-4.5$ & $4.8-5.0$ \\
Surface tension at CMC $(\mathbf{m N} / \mathbf{m})$ & 43.9 & 37.0 \\
$p \mathbf{C 2 0}{ }^{\mathrm{a}}$ & 2.72 & 3.00 \\
$A\left(\AA^{\mathbf{2}}\right)^{\mathrm{b}}$ & 66.5 & 45.1 \\
\hline${ }^{\text {a }}$ Minus logarithm of the concentration required to diminish the surface tension of water by $20 \mathrm{mN} / \mathrm{m} .{ }^{\mathrm{b}}$ Area \\
occupied per molecule adsorbed at the saturated interface.
\end{tabular}

\section{Materials and Methods}

\subsection{Enzymes and Reagents}

CGTase from Thermoanaerobacter sp. (Toruzyme 3.0L) was kindly provided by Novozymes A/S (Bagsværd, Denmark). CGTase from Geobacillus sp. (CGT-SL) was from Amano Enzyme Inc. (Nagoya, Japan). Both CGTases were partially purified using a PD-10 desalting column (GE Healthcare). CGTases from T. thermosulfurigenes EM1 and B. circulans strain 251 were kindly provided in purified form by L. Dijkhuizen (Groningen University, The Netherlands). The $\alpha$-glucosidase (EC 3.2.1.20) from Saccharomyces cerevisiae was from Boehringer Mannheim. $\beta$-Cyclodextrin was purchased from Sigma. $p$-Nitrophenyl- $\alpha$-D-maltoheptaoside-4,6-O-ethylidene (EPS) was from Boehringer Mannheim. Starch from potato Paselli SA2 (partially hydrolyzed with a mean degree of polymerization of 50) was kindly provided by Avebe (Foxhol, The Netherlands). Tert-butyl alcohol was from Fluka. All other reagents and solvents were of the highest purity grade available.

\subsection{Activity Assay}

The transglycosylation (disproportionation) activity of CGTase was measured on the basis of the method described by Nakamura et al. [55], adapted to 96-well plates. EPS ( $p$-nitrophenyl- $\alpha$-Dmaltoheptaoside-4-6-O-ethylidene) was as the glucosyl donor and maltose the acceptor. In this assay EPS is first cleaved and the maltose molecule is then linked to the free reducing end. Thereafter, the $p$-nitrophenol is released from the reaction product by the action of $\alpha$-glucosidase. In particular, $20 \mu \mathrm{L}$ of a maltose solution $(50 \mathrm{mM})$ were mixed with $10 \mu \mathrm{L}$ of an EPS solution $(30 \mathrm{mM})$ and $65 \mu \mathrm{L}$ of $0.2 \mathrm{M}$ phosphate buffer ( $\mathrm{pH}$ 7.0). The reaction, performed by triplicate, started when $5 \mu \mathrm{L}$ of enzymatic solution was added. The 96 -well plate was incubated at $60{ }^{\circ} \mathrm{C}$ for $20 \mathrm{~min}$. The transglycosylation was stopped with $10 \mu \mathrm{L}$ of $1 \mathrm{M} \mathrm{HCl}$ and the mixture was incubated at $60^{\circ} \mathrm{C}$ for $10 \mathrm{~min}$. Thereafter it was neutralized with $10 \mu \mathrm{L}$ of $1 \mathrm{M} \mathrm{NaOH}$. The $\alpha$-glucosidase (EC 3.2.1.20) from S. cerevisiae was then added $(0.005 \mathrm{U})$ and the mixture was kept at $25^{\circ} \mathrm{C}$ for $1 \mathrm{~h}$. Finally, $\mathrm{Na}_{2} \mathrm{CO}_{3}(1 \mathrm{M})$ was added to a final volume of $200 \mu \mathrm{L}$ and the absorbance was measured at $401 \mathrm{~nm}$. A calibration curve with $p$-nitrophenol was made from a stock solution of $0.74 \mathrm{mg} / \mathrm{mL}$. Different volumes between $0-10 \mu \mathrm{L}$ were taken by triplicate and conveniently diluted with $0.2 \mathrm{M}$ phosphate buffer to a total volume of $100 \mu \mathrm{L}$. One unit of activity (U) was established as that corresponding to the release of $1 \mu \mathrm{mol}$ of $p$-nitrophenol per min under these conditions. 


\subsection{Enzymatic Synthesis of Tert-Butyl Glucosides}

Typical reaction mixtures contained 30\% v/v tert-butyl alcohol, a 3\% w/v sugar donor (Paselli SA2 starch, maltose, or cyclodextrins) and $0.4 \mathrm{U} / \mathrm{mL}$ CGTase (transglycosylation activity, chapter 3.2), in $10 \mathrm{mM}$ sodium citrate buffer ( $\mathrm{pH}$ 5.5). Reaction mixtures were incubated at $250 \mathrm{rpm}$ in an orbital incubator at $60^{\circ} \mathrm{C}$. At regular time intervals, aliquots were removed and analyzed by TLC and HPLC. Controls without enzyme, tert-butyl alcohol, and/or sugar donor were also performed to rule out the presence of non-enzymatic products.

\subsection{TLC and HPLC Analyses}

Reaction samples were filtered on UltraFree centrifugal filters $(0.45 \mu \mathrm{m}$, Millipore, Burlington, MA, USA) and analyzed in silica gel plates $(10 \times 5 \mathrm{~cm}$, Merck) developed with ethyl acetate/methanol/water $(77 / 15 / 8, v / v / v)$. Spots containing the residual carbohydrates and products were visualized after staining with a p-methoxybenzaldehyde solution (ethanol/sulphuric acid/p-methoxybenzaldehyde, $19 / 1 / 1, v / v / v$ ) and heated at $90^{\circ} \mathrm{C}$ for $15 \mathrm{~min}$. The reaction progress was followed by normal-phase high-performance liquid chromatography (HPLC) employing a quaternary pump (Delta 600, Waters, Milford, MA, USA) and a Luna NH2 column $(250 \mathrm{~mm} \times 4.6 \mathrm{~mm}, 5 \mu \mathrm{m}$, Phenomenex). The starting mobile phase was acetonitrile:water $78: 22(\mathrm{v} / \mathrm{v})$ and the gradient is outlined in Table 3 . The solvents were conditioned with helium and the flow rate was $1.0 \mathrm{~mL} / \mathrm{min}$. The temperature of the column was kept constant at $30^{\circ} \mathrm{C}$. An evaporative light-scattering detector (model PL-ELS 1000, Polymer Laboratories, Salop, UK) was used and fixed to a nebulization and evaporation temperatures of $80^{\circ} \mathrm{C}$ and $90^{\circ} \mathrm{C}$, respectively. The data obtained were analyzed using the Millennium Software, employing purified compounds as external standards for calibration.

Table 3. HPLC gradient profile.

\begin{tabular}{ccc}
\hline Time & Acetonitrile & Water \\
\hline $0-12 \mathrm{~min}$ & $78 \%$ & $22 \%$ \\
$12-15 \mathrm{~min}$ & $78 \% \rightarrow 50 \%$ & $22 \% \rightarrow 50 \%$ \\
$15-20 \mathrm{~min}$ & $50 \%$ & $50 \%$ \\
$20-21 \mathrm{~min}$ & $50 \% \rightarrow 78 \%$ & $50 \% \rightarrow 22 \%$ \\
$21-30 \mathrm{~min}$ & $78 \%$ & $22 \%$ \\
\hline
\end{tabular}

\subsection{Purification of Tert-Butyl Glucosides}

The reaction mixture $(100 \mathrm{~mL}$ ) contained 30\% v/v tert-butyl alcohol, 3\% w/v Paselli SA2 (sugar donor), and $0.4 \mathrm{U} / \mathrm{mL}$ CGTase (transglycosylation activity) in $10 \mathrm{mM}$ sodium citrate buffer ( $\mathrm{pH}$ 5.5). The mixture was incubated at $250 \mathrm{rpm}$ in an orbital shaker and $60^{\circ} \mathrm{C}$. After $200 \mathrm{~h}$ the reaction was stopped, and products were purified as follows. Reaction medium was filtered $(0.45 \mu \mathrm{m}$, Millipore) and water and residual tert-butyl alcohol were evaporated by rotary evaporation at $60^{\circ} \mathrm{C}$. The dried products were then dissolved in a mixture of acetonitrile:water $(88: 12 \mathrm{v} / \mathrm{v})$ and purified in a semipreparative HPLC pump (Delta 600, Waters) coupled to a Kromasil-NH2 column (250 mm $\times 10 \mathrm{~mm}$, Analisis Vinicos, Spain) and to a refraction-index detector (model 9040, Varian, Palo Alto, CA, USA). Compounds were eluted in an isocratic regime using acetonitrile:water $(88: 12 \mathrm{v} / \mathrm{v})$ as mobile phase at a flow rate of $8.0 \mathrm{~mL} / \mathrm{min}$. Fractions containing the desired products were collected and pooled. The mobile phase was evaporated by rotary evaporation at $60{ }^{\circ} \mathrm{C}$ and the dried products were stored at $-20^{\circ} \mathrm{C}$. The purity of the isolated compounds was assessed by analytical HPLC. The equivalent isolated yields were approximately $1.1 \mathrm{~g}$ of tert-butyl-glucoside and $0.2 \mathrm{~g}$ of tert-butyl-maltoside.

\subsection{Mass Spectrometry (MS)}

The MS analysis of purified glucosides was carried out with a mass spectrometer equipped with hybrid QTOF analyzer (QSTAR, Pulsar i, AB Sciex, Madrid, Spain). Samples were analyzed by direct 
infusion using electrospray ionization in positive reflector mode. Methanol containing $1 \%$ of $\mathrm{NH}_{4} \mathrm{OH}$ was employed as ionizing phase.

\subsection{Nuclear Magnetic Resonance (NMR)}

NMR spectra were determined on a Varian Unit (1H-NMR, $500 \mathrm{MHz}$; 13C-NMR, $125 \mathrm{MHz}$ ) spectrometer, equipped with a gradient unit and a reverse probe. Samples $(6-10 \mathrm{mg})$ were dissolved in $0.6 \mathrm{~mL}$ of semiheavy water (HDO and the spectra were obtained at $40^{\circ} \mathrm{C}$. Proton chemical shifts were referred to residual HDO (4.61 ppm). Carbon chemical shifts were referred to external acetone (31.07 ppm). 2D-homo- (DQCOSY, TOCSY (HOHAHA), NOESY) and hetero- (HMQC and HMBC) NMR experiments were carried out by using the standard software from Varian.

\subsection{Enzyme Purification}

Thermoanaerobacter sp. CGTase was purified from the commercial extract (Toruzyme 3.0L, Novozymes A/S, Bagsværd, Denmark)) through successive steps of ion exchange and affinity chromatography on a FPLC LCC-500 equipment (Pharmacia, Sweden). The commercial extract was dialyzed against $20 \mathrm{mM}$ Tris- $\mathrm{HCl}$ buffer ( $\mathrm{pH}$ 7.5) and loaded onto a DEAE-Sepharose column equilibrated with the same buffer. Proteins were eluted using a linear salt gradient from 0 to $1 \mathrm{M}$ of $\mathrm{NaCl}$ in the Tris- $\mathrm{HCl}$ buffer. The fractions containing CGTase were pooled, dialyzed against $10 \mathrm{mM}$ acetate buffer ( $\mathrm{pH}$ 5.5), and concentrated in an ultrafiltration cell (Amicon, Merck KGaA, Darmstadt, Germany) fitted with a $10 \mathrm{kDa}$ membrane. The concentrate was then loaded onto a column of Sepharose activated with $\alpha$-cyclodextrin and equilibrated with the acetate buffer. After washing, the proteins were eluted with the above buffer containing $\alpha$-cyclodextrin $(10 \mathrm{mg} / \mathrm{mL})$. CGTase-enriched fractions were merged, concentrated as before and stored at $-20{ }^{\circ} \mathrm{C}$ until its use. Purity was assessed by Coomasie-Blue stained SDS-PAGE electrophoresis.

\subsection{Critical Micellar Concentration}

The measurement of the surface tension in $\mathrm{H}_{2} \mathrm{O}$ was carried out at $20^{\circ} \mathrm{C}$ using different aqueous solutions of alkyl glycosides at various concentrations, according to the Wilhelmy plate method [56] with a tensiometer (Processor tensiometer K-12, Krüss, Hamburg, Germany), which measures the real tension values at the equilibrium. Critical micelle concentrations (CMCs) were calculated graphically from the sharp change in the slope of the surface tension values vs. the logarithm of surfactant concentration, expressed in $\mathrm{mM}$.

The average area $(A)$ occupied per molecule of surfactant adsorbed in the saturated water-air interface was estimated from the equation

$$
A=\frac{10^{16}}{N_{A}} \times \Gamma_{m}
$$

in which $N_{A}$ is the Avogadro's number, $\Gamma_{m}$ is the maximum concentration of surfactant molecules adsorbed in the saturated interface $\left(\mathrm{moles} / \mathrm{cm}^{2}\right)$, and the resulting $A$ is expressed in squared Angstroms. The value of $\Gamma_{m}$ can be calculated by applying the Gibbs equation:

$$
\Gamma_{m}=-\frac{\left(\frac{d \gamma}{d \log c}\right)}{2.3030 \cdot n \cdot R \cdot T}
$$

where $(\mathrm{d} \gamma / \mathrm{d} \log \mathrm{c})$ is the maximum slope of the linear plot representing surface tension vs. logarithm of surfactant concentration that appears immediately below the $\mathrm{CMC}, \mathrm{R}=8.31 \mathrm{~J} \cdot \mathrm{mol}^{-1} \cdot \mathrm{K}^{-1}$, and $T$ is the temperature in $\mathrm{K}$. The value of $n$ (the number of species into which the surfactant dissociates) is taken as one for nonionic surfactants. 


\section{Conclusions}

The present work describes, for the first time, the enzymatic synthesis of $\alpha$-glucosides of a tertiary alcohol (tert-butyl alcohol). The process is catalyzed by the enzyme CGTase, in particular from the strains Thermoanaerobacter sp. and T. thermosulfurigenes. The biotransformation is carried out under mild conditions, using starch as glucose donor, and gives rise to a significant yield (44\%) of $\alpha$-glucoside (major product) and $\alpha$-maltoside (minor product). The synthesized tert-butyl-O- $\alpha$-D-glucopyranoside exhibited the typical surfactant behavior and its properties were comparable to those of the related $\alpha$-octyl derivative.

Supplementary Materials: The following are available online at http://www.mdpi.com/2073-4344/9/7/575/s1, Figure S1: ESI-TOF spectrum (positive mode) of tert-butyl-O- $\alpha$-D-glucopyranoside, Figure S2: ESI-TOF spectrum (positive mode) of tert-butyl-O- $\alpha$-D-maltoside.

Author Contributions: F.J.P., M.A. and A.O.B. conceived and designed the experiments; H.G.-A., J.L.G.-A. and C.U. carried out most of the experiments; M.B. performed the product characterization by NMR; F.C. and J. L.P. contributed with surfactant analysis; and F.J.P. and H.G.-A. wrote the paper, which was improved by the rest of authors.

Funding: This work was supported by a grant from the Spanish Ministry of Economy and Competitiveness (Grants BIO2016-76601-C3-1-R). We thank the support of the EU COST-Action CM1303 on Systems Biocatalysis. We thank Spanish Ministry of Education for a FPU grant to J.L.G.-A.

Acknowledgments: We thank L. Dijkhuizen (Groningen University, The Netherlands) for providing us CGTases from Thermoanaerobacterium thermosulfurigenes EM1 and Bacillus circulans. We are grateful to Yoshihiko Hirose (Enzyme Techno) for the supply of CGTase from Geobacillus sp. We thank Ramiro Martinez (Novozymes A/S) for supplying Toruzyme and for significant suggestions. We acknowledge support of the publication fee by the CSIC Open Access Publication Support Initiative through its Unit of Information Resources for Research (URICI).

Conflicts of Interest: The authors declare no conflict of interest.

\section{References}

1. Uitdehaag, J.C.M.; Van Der Veen, B.A.; Dijkhuizen, L.; Dijkstra, B.W. Catalytic mechanism and product specificity of cyclodextrin glycosyltransferase, a prototypical transglycosylase from the $\alpha$-amylase family. Enzyme Microb. Technol. 2002, 30, 295-304. [CrossRef]

2. Leemhuis, H.; Kelly, R.M.; Dijkhuizen, L. Engineering of cyclodextrin glucanotransferases and the impact for biotechnological applications. Appl. Microbiol. Biotechnol. 2010, 85, 823-835. [CrossRef] [PubMed]

3. Fenyvesi, É.; Vikmon, M.; Szente, L. Cyclodextrins in Food Technology and Human Nutrition: Benefits and Limitations. Crit. Rev. Food Sci. Nutr. 2016, 56, 1981-2004. [CrossRef] [PubMed]

4. Alcalde, M.; Plou, F.J.; Andersen, C.; Martin, M.T.; Pedersen, S.; Ballesteros, A. Chemical modification of lysine side chains of cyclodextrin glycosyltransferase from Thermoanaerobacter causes a shift from cyclodextrin glycosyltransferase to alpha-amylase specificity. FEBS Lett. 1999, 445, 333-337. [CrossRef]

5. Wind, R.D.; Buitelaar, R.M.; Dijkhuizen, L. Engineering of factors determining alpha-amylase and cyclodextrin glycosyltransferase specificity in the cyclodextrin glycosyltransferase from Thermoanaerobacterium thermosulfurigenes EM1. Eur. J. Biochem. 1998, 253, 598-605. [CrossRef]

6. Tonkova, A. Bacterial cyclodextrin glucanotransferase. Enzyme Microb. Technol. 1998, 22, 678-686. [CrossRef]

7. Alcalde, M.; Plou, F.J.; Martin, M.T.; Valdes, I.; Mendez, E.; Ballesteros, A. Succinylation of cyclodextrin glycosyltransferase from Thermoanaerobacter sp. 501 enhances its transferase activity using starch as donor. J. Biotechnol. 2001, 86, 71-80. [CrossRef]

8. Martin, M.T.; Cruces, M.A.; Alcalde, M.; Plou, F.J.; Bernabe, M.; Ballesteros, A. Synthesis of maltooligosyl fructofuranosides catalyzed by immobilized cyclodextrin glucosyltransferase using starch as donor. Tetrahedron 2004, 60, 529-534. [CrossRef]

9. Torres, P.; Poveda, A.; Jimenez-Barbero, J.; Parra, J.L.; Comelles, F.; Ballesteros, A.O.; Plou, F.J. Enzymatic synthesis of $\alpha$-glucosides of resveratrol with surfactant activity. Adv. Synth. Catal. 2011, 353, 1077-1086. [CrossRef]

10. Mathew, S.; Adlercreutz, P. Regioselective glycosylation of hydroquinone to $\alpha$-arbutin by cyclodextrin glucanotransferase from Thermoanaerobacter sp. Biochem. Eng. J. 2013, 79, 187-193. [CrossRef] 
11. Monthieu, C.; Guibert, A.; Taravel, F.R.; Nardin, R.; Combes, D. Purification and characterisation of polyglucosyl-fructosides produced by means of cyclodextrin glucosyl transferase. Biocatal. Biotransf. 2003, 21, 7-15. [CrossRef]

12. Martin, M.T.; Alcalde, M.; Plou, F.J.; Dijkhuizen, L.; Ballesteros, A. Synthesis of malto-oligosaccharides via the acceptor reaction catalyzed by cyclodextrin glycosyltransferases. Biocatal. Biotransf. 2001, 19, 21-35. [CrossRef]

13. Han, R.; Ge, B.; Jiang, M.; Xu, G.; Dong, J.; Ni, Y. High production of genistein diglucoside derivative using cyclodextrin glycosyltransferase from Paenibacillus macerans. J. Ind. Microbiol. Biotechnol. 2017, 44, 1343-1354. [CrossRef] [PubMed]

14. Gonzalez-Alfonso, J.L.; Leemans, L.; Poveda, A.; Jiménez-Barbero, J.; Ballesteros, A.O.; Plou, F.J. Efficient $\alpha$-glucosylation of epigallocatechin gallate catalyzed by cyclodextrin glucanotransferase from Thermoanaerobacter sp. J. Agric. Food Chem. 2018, 66, 7402-7408. [CrossRef] [PubMed]

15. Jun, H.K.; Bae, K.M.; Kim, S.K. Production of 2-O-alpha-D-glucopyranosyl L-ascorbic acid using cyclodextrin glucanotransferase from Paenibacillus sp. Biotechnol. Lett. 2001, 23, 1793-1797. [CrossRef]

16. Miranda-Molina, A.; Marquina-Bahena, S.; López-Munguía, A.; Álvarez, L.; Castillo, E. Regioselective glucosylation of inositols catalyzed by Thermoanaerobacter sp. CGTase. Carbohydr. Res. 2012, 360, $93-101$. [CrossRef] [PubMed]

17. Nakano, H.; Kitahata, S. Application of cyclodextrin glucanotransferase to the synthesis of useful oligosaccharides and glycosides. In Handbook of Industrial Biocatalysts; Hou, C.T., Ed.; Taylor and Francis: Boca Raton, FL, USA, 2005; pp. 419-435.

18. Do, H.; Sato, T.; Kirimura, K.; Kino, K.; Usami, S. Enzymatic synthesis of L-menthyl alpha-maltoside and L-menthyl alpha-maltooligosides from L-menthyl alpha-glucoside by cyclodextrin glucanotransferase. $J$. Biosci. Bioeng. 2002, 94, 119-123. [CrossRef]

19. Kelly, R.M.; Dijkhuizen, L.; Leemhuis, H. The evolution of cyclodextrin glucanotransferase product specificity. Appl. Microbiol. Biotechnol. 2009, 84, 119-133. [CrossRef]

20. Kurimoto, M.; Tabuchi, A.; Mandai, T.; Shibuya, T.; Chaen, H.; Fukuda, S.; Sugimoto, T.; Tsujisaka, Y. Synthesis of glycosyl-trehaloses by cyclomaltodextrin glucanotransferase through the transglycosylation reaction. Biosci. Biotechnol. Biochem. 1997, 61, 1146-1149. [CrossRef]

21. Shimoda, K.; Hara, T.; Hamada, H.; Hamada, H. Synthesis of curcumin $\beta$-maltooligosaccharides through biocatalytic glycosylation with Strophanthus gratus cell culture and cyclodextrin glucanotransferase. Tetrahedron Lett. 2007, 48, 4029-4032. [CrossRef]

22. González-Alfonso, J.; Rodrigo-Frutos, D.; Belmonte-Reche, E.; Peñalver, P.; Poveda, A.; Jiménez-Barbero, J.; Ballesteros, A.O.; Hirose, Y.; Polaina, J.; Morales, J.; et al. Enzymatic synthesis of a novel pterostilbene $\alpha$-glucoside by the combination of cyclodextrin glucanotransferase and amyloglucosidase. Molecules 2018, 23, 1271. [CrossRef] [PubMed]

23. González-Alfonso, J.L.; Míguez, N.; Padilla, J.D.; Leemans, L.; Poveda, A.; Jiménez-Barbero, J.; Ballesteros, A.O.; Sandoval, G.; Plou, F.J. Optimization of regioselective $\alpha$-glucosylation of hesperetin catalyzed by cyclodextrin glucanotransferase. Molecules 2018, 23, 2885. [CrossRef] [PubMed]

24. Han, R.; Liu, L.; Shin, H.; Chen, R.R.; Du, G.; Chen, J. Site-saturation engineering of lysine 47 in cyclodextrin glycosyltransferase from Paenibacillus macerans to enhance substrate specificity towards maltodextrin for enzymatic synthesis of 2-O-D-glucopyranosyl-L-ascorbic acid (AA-2G). Appl. Microbiol. Biotechnol. 2013, 97, 5851-5860. [CrossRef] [PubMed]

25. Wind, R.D.; Uitdehaag, J.C.M.; Buitelaar, R.M.; Dijkstra, B.W.; Dijkhuizen, L. Engineering of cyclodextrin product specificity and $\mathrm{pH}$ optima of the thermostable cyclodextrin glycosyltransferase from Thermoanaerobacterium thermosulfurigenes EM1. J. Biol. Chem. 1998, 273, 5771-5779. [CrossRef] [PubMed]

26. Koo, Y.S.; Lee, H.W.; Jeon, H.Y.; Choi, H.J.; Choung, W.J.; Shim, J.H. Development and characterization of cyclodextrin glucanotransferase as a maltoheptaose-producing enzyme using site-directed mutagenesis. Protein Eng. Des. Sel. 2015, 28, 531-537. [CrossRef] [PubMed]

27. Martin, M.T.; Plou, F.J.; Alcalde, M.; Ballesteros, A. Immobilization on Eupergit C of cyclodextrin glucosyltransferase (CGTase) and properties of the immobilized biocatalyst. J. Mol. Catal. B Enzym. 2003, 21, 299-308. [CrossRef]

28. Iyer, J.L.; Shetty, P.; Pai, J.S. Immobilisation of cyclodextrin glucanotransferase from Bacillus circulans ATCC 21783 on purified seasand. J. Ind. Microbiol. Biotechnol. 2003, 30, 47-51. [CrossRef] 
29. Delbourg, M.F.; Drouet, P.; Demoraes, F.; Thomas, D.; Barbotin, J.N. Effect of PEG and other additives on cyclodextrin production by Bacillus macerans cyclomaltodextrin-glycosyl-transferase. Biotechnol. Lett. 1993, 15, 157-162. [CrossRef]

30. Morita, T.; Yoshida, N.; Karube, I. A novel synthesis method for cyclodextrins from maltose in water-organic solvent systems. Appl. Biochem. Biotechnol. 1996, 56, 311-324. [CrossRef]

31. Blackwood, A.D.; Bucke, C. Addition of polar organic solvents can improve the product selectivity of cyclodextrin glycosyltransferase-Solvent effects on CGTase. Enzyme Microb. Technol. 2000, 27, 704-708. [CrossRef]

32. Qi, Q.S.; Zimmermann, W. Cyclodextrin glucanotransferase: From gene to applications. Appl. Microbiol. Biotechnol. 2005, 66, 475-485. [CrossRef] [PubMed]

33. van Rantwijk, F.; Oosterom, M.W.V.; Sheldon, R.A. Glycosidase-catalysed synthesis of alkyl glycosides. J. Mol. Catal. B Enzym. 1999, 6, 511-532. [CrossRef]

34. Svasti, J.; Phongsak, T.; Sarnthima, R. Transglucosylation of tertiary alcohols using cassava beta-glucosidase. Biochem. Biophys. Res. Commun. 2003, 305, 470-475. [CrossRef]

35. Huneke, F.U.; Bailey, D.; Nucci, R.; Cowan, D. Sulfolobus solfataricus $\beta$-glycosidase-catalysed synthesis of sugar-alcohol conjugates in the presence of organic solvents. Biocatal. Biotransf. 2000, 18, 291-299. [CrossRef]

36. Mazzaferro, L.S.; Weiz, G.; Braun, L.; Kotik, M.; Pelantová, H.; Křen, V.; Breccia, J.D. Enzyme-mediated transglycosylation of rutinose (6-O- $\alpha$-L-rhamnosyl-D-glucose) to phenolic compounds by a diglycosidase from Acremonium sp. DSM 24697. Biotechnol. Appl. Biochem. 2019, 66, 53-59. [CrossRef] [PubMed]

37. Yang, J.; Pérez, B.; Anankanbil, S.; Li, J.; Gao, R.; Guo, Z. Enhanced synthesis of alkyl galactopyranoside by Thermotoga naphthophila $\beta$-galactosidase catalyzed transglycosylation: Kinetic insight of a functionalized ionic liquid-mediated system. ACS Sustain. Chem. Eng. 2017, 5, 2006-2014. [CrossRef]

38. García, C.; Hoyos, P.; Hernáiz, M.J. Enzymatic synthesis of carbohydrates and glycoconjugates using lipases and glycosidases in green solvents. Biocatal. Biotransf. 2018, 36, 131-140. [CrossRef]

39. von Rybinski, W.; Hill, K. Alkyl polyglycosides-Properties and applications of a new class of surfactants. Angew. Chem. Int. Ed. 1998, 37, 1328-1345. [CrossRef]

40. Sarney, D.B.; Vulfson, E.N. Application of enzymes to the synthesis of surfactants. Trends Biotechnol. 1995, 13, 164-172. [CrossRef]

41. Gonzalez-Alfonso, J.L.; Peñalver, P.; Ballesteros, A.O.; Morales, J.C.; Plou, F.J. Effect of $\alpha$-glucosylation on the stability, antioxidant properties, toxicity, and neuroprotective activity of (-)-epigallocatechin gallate. Front. Nutr. 2019, 6. [CrossRef]

42. Plou, F.J.; Martin, M.T.; Gomez de Segura, A.; Alcalde, M.; Ballesteros, A. Glucosyltransferases acting on starch or sucrose for the synthesis of oligosaccharides. Can. J. Chem. 2002, 80, 743-752. [CrossRef]

43. Svensson, D.; Ulvenlund, S.; Adlercreutz, P. Efficient synthesis of a long carbohydrate chain alkyl glycoside catalyzed by cyclodextrin glycosyltransferase (CGTase). Biotech. Bioeng. 2009, 104, 854-861. [CrossRef] [PubMed]

44. Nakano, H.; Kitahata, S.; Tominaga, Y.; Kiku, Y.; Ando, K.; Kawashima, Y.; Takenishi, S. Syntheses of glucosides with trimethylolpropane and 2 related polyol moieties by cyclodextrin glucanotransferase and their esterification by lipase. J. Ferment. Bioeng. 1992, 73, 237-238. [CrossRef]

45. Larsson, J.; Svensson, D.; Adlercreutz, P. $\alpha$-Amylase-catalysed synthesis of alkyl glycosides. J. Mol. Catal. $B$ Enzym. 2005, 37, 84-87. [CrossRef]

46. Otto, R.T.; Bornscheuer, U.T.; Syldatk, C.; Schmid, R.D. Synthesis of aromatic n-alkyl-glucoside esters in a coupled $\beta$-glucosidase and lipase reaction. Biotechnol. Lett. 1998, 20, 437-440. [CrossRef]

47. Fischer, L.; Bromann, R.; Kengen, S.W.M.; de Vos, W.M.; Wagner, F. Catalytical potency of $\beta$-glucosidase from the extremophile Pyrococcus furiosus in glucoconjugate synthesis. Bio/Technology 1996, 14, 88-91. [CrossRef]

48. Jiang, Z.; Zhu, Y.; Li, L.; Yu, X.; Kusakabe, I.; Kitaoka, M.; Hayashi, K. Transglycosylation reaction of xylanase B from the hyperthermophilic Thermotoga maritima with the ability of synthesis of tertiary alkyl $\beta$-D-xylobiosides and xylosides. J. Biotechnol. 2004, 114, 125-134. [CrossRef]

49. Kongsaeree, P.T.; Ratananikom, K.; Choengpanya, K.; Tongtubtim, N.; Sujiwattanarat, P.; Porncharoennop, C.; Onpium, A.; Svasti, J. Substrate specificity in hydrolysis and transglucosylation by family $1 \beta$-glucosidases from cassava and Thai rosewood. J. Mol. Catal. B Enzym. 2010, 67, 257-265. [CrossRef]

50. Simerská, P.; Kuzma, M.; Monti, D.; Riva, S.; Macková, M.; Křen, V. Unique transglycosylation potential of extracellular $\alpha$-D-galactosidase from Talaromyces flavus. J. Mol. Catal. B Enzym. 2006, 39, 128-134. [CrossRef] 
51. Tanaka, T.; Kikuta, N.; Kimura, Y.; Shoda, S.I. Metal-catalyzed stereoselective and protecting-group-free synthesis of 1,2-cis-glycosides using 4,6-dimethoxy-1,3,5-triazin-2-yl glycosides as glycosyl donors. Chem. Lett. 2015, 44, 846-848. [CrossRef]

52. Zamost, B.L.; Nielsen, H.K.; Starnes, R.L. Thermostable enzymes for industrial applications. J. Ind. Microbiol. 1991, 8, 71-81. [CrossRef]

53. De Roode, B.M.; Franssen, M.C.R.; Van Der Padt, A.; Boom, R.M. Perspectives for the industrial enzymatic production of glycosides. Biotechnol. Prog. 2003, 19, 1391-1402. [CrossRef] [PubMed]

54. Wasylewski, Z.; Kozik, A. Protein-nonionic detergent interaction-interaction of bovine serum-albumin with alkyl glucosides studied by equilibrium dialysis and infrared spectroscopy. Eur. J. Biochem. 1979, 95, 121-126. [CrossRef] [PubMed]

55. Nakamura, A.; Haga, K.; Yamane, K. The transglycosylation reaction of cyclodextrin glucanotransferase is operated by a ping-pong mechanism. FEBS Lett. 1994, 337, 66-70. [CrossRef]

56. International Standard ISO 304-1985. Surface active agents. Determination of surface tension by drawing up liquid films. Available online: https://www.iso.org/standard/4238.html (accessed on 29 June 2019).

(C) 2019 by the authors. Licensee MDPI, Basel, Switzerland. This article is an open access article distributed under the terms and conditions of the Creative Commons Attribution (CC BY) license (http://creativecommons.org/licenses/by/4.0/). 